\title{
Use of Lecture Method and Concept Mapping Strategies in Enhancing Primary School Pupils Achievement and Retention in Social Studies at Makurdi, Nigeria
}

\author{
Grace Terdoo Waya ljoyah ${ }^{1^{*}}$, Rebecca Ashikor Moji ${ }^{1}$, Joy Ojorumi ljoyah ${ }^{2}$ \\ ${ }^{1}$ Department of Curriculum and Teaching, Benue State University, P.M.B. 102119, Makurdi, \\ Nigeria \\ ${ }^{2}$ Department of Agricultural Education, University of Agriculture, P.M.B. 2373, Makurdi, Nigeria \\ *E-mail address: mikejoy2005@yahoo.com
}

Keywords: teaching strategies, academic performance, retention ability, social studies

\begin{abstract}
This study investigated the use of concept mapping strategy with the lecture teaching method as it affects achievement and retention ability of primary six pupils in social studies. A total of 244 primary six pupils from Makurdi local government area of Benue State, Nigeria, were randomly selected. The total number of boys was 123, while that of girls was 121. A Quasi experimental design was adopted for the study. Two instruments were used for data collection, namely: the social studies achievement test (SSAT) and social studies retention test (SSRT). The data collected were subjected to independent sample t-test and paired sample t-test, at a probability level of .05 to indicate statistical significance. The finding revealed that concept mapping strategy was more effective in enhancing achievement score of pupils as compared to the lecture method. Pupils taught using concept mapping recorded a mean achievement score of $63.0 \%$, as compared to those taught using the lecture method strategy with a mean achievement score of $49.9 \%$. Though, the mean achievement scores of pupils taught using the two different teaching techniques showed significant difference, however, the mean retention score of pupils was not significantly $(\mathrm{P}<0.05)$ affected, hence hypothesis was upheld. The implication of study showed that social studies teachers should adopt concept mapping strategy as an effective teaching-learning technique in improving pupils academic performance in school.
\end{abstract}

\section{INTRODUCTION}

Lecture method is a pedagogical strategy that involves the teacher telling his or her pupils what he/she wants to know and the pupils listening to the teacher and sometimes taking down notes on what the teacher is saying or merely committing same to memory (Ijoh et al., 1996). The major advantage of lecture method is that it is time saving, easy to prepare and many students can be taught at the same time (Okam, 2000). Its disadvantages according to Shamija (2008), does not cater for individual differences, brings boredom by making pupils passive instead of active in class activities and learners initiative is not considered.

Concept mapping is also a teaching technique which permits a visual representation of concepts concerning a topic and reveals the relationship among them as a whole (Havva and Cemal, 2008). According to Ezeudu (1995) and Utulu (2007), concept mapping can be defined as a graphic representation of concepts showing the relationship between the ideas, through the use of linking words. Concept mapping motivates young learners and encourages critical thinking, innovation and creativity (Utulu, 2007).

In Nigeria, the primary school social studies curriculum is centered on the objectives of primary education as stipulated by the National policy on education (FRN, 2004). If social studies as a discipline is to achieve all of its objectives such as developing skill, acquisition of knowledge, appreciation of national diversity and positive attitude in making a personal contribution for a united Nigeria, then it has to be taken seriously from the primary school level (Nworgu, 2003). 
Social studies educators have expressed concern about the decline in students academic performance in the subject and attributed one of the major reasons to the teaching strategies they use (Imoko and Agwagah, 2006). Concept mapping strategy has been proven to be effective in improving performance and retention in recent researches carried out in subjects like Mathematics, Biology, Physics, Chemistry, Religion and Language (Imoko and Agwagah, 2006). Social studies which deals with man and environment (society) cannot be taught as Mathematics, Chemistry, Physics or Religion whose facts are always constant. The society is not static, new things keep revolving and so new ideas. On this basis, social studies educators have acknowledged the need for indepth research geared towards improving the quality of social studies teaching in the Nigerian primary schools that will enhance pupils achievement and retention ability.

There is also scarcity of empirical studies on the use of concept mapping as a teaching strategy in improving pupils achievement and retention, particularly in social studies. The study therefore aimed at investigating the use of the conventional lecture method and concept mapping strategy in promoting primary school pupils achievement and retention ability in social studies with the objective of determining the more effective teaching method that will enhance academic performance and retention ability of pupils in social studies.

\section{METHODOLOGY}

\subsection{Study location and target population}

The study was carried out in Makurdi metropolis, Benue State, Nigeria, to investigate the use of lecture and concept mapping strategies in enhancing primary school pupils achievement and retention in social studies. The target population was limited to public primary schools in Makurdi metropolis. Public primary schools (regarded as schools for the poor and the less priviledged) were chosen to reduce parental and school type influence. Primary six pupils were

chosen because they are assumed to have the ability to search for scientific materials and possess a strong and natural desire for learning (Ozden and Gultekin, 2008).

\subsection{Sampling and sample size}

Random sampling was used to select schools. The schools sampled must have classes 1 to 6 , is a public primary school and the school authorities having the willingness for the experiment to be carried out in their schools. A sample size of 244 pupils was used from six schools. The total number of boys was 123, while that of girls was 121. Three schools were assigned to the experimental group (to be taught using the concept mapping strategy), while the other three groups were assigned to the control group (to be taught using the lecture method). The grouping was done by balloting. There were 40 pupils in primary 6 , from each school.

\subsection{Design, instruments and analysis}

The design adopted for this study was a Pre-Post Quasi experimental design. The design according to Ali (1996), was considered appropriate because it established a cause and effect relationship between the independent and dependent variables. The independent variables were lecture method and concept mapping, while the dependent variables were achievement and retention. Lesson plans on five topics under 'Marriage' in social studies were drawn and taught using the concept mapping strategy and lecture method respectively, for the experimental and control groups.

The instruments used were the social studies achievement test (SSAT) and social studies retention test (SSRT). The SSAT and SSRT are researchers-made instruments based on the 'Test Blue Print' as developed by Nworgu (2003), consisting of lower order questions and higher order questions of the cognitive domain. The SSAT and SSRT were administered to both the experimental and control groups, but the SSAT was reshuffled for the SSRT. The instruments were validated for content validity and reliability. The pre-SSAT was administered on the first day of class. After the five weeks of teaching, using the concept mapping strategy and lecture method respectively, for the experimental and control groups, the post-SSAT was administered and scores sorted out and analyzed. The SSRT was administered 3 weeks after the post-SSAT in order to test the pupil's 
retention level of the topics being taught using the concept mapping and lecture methods. The analysis of paired samples t-test was used to assess the difference across the two groups.

Data for this study were analyzed using descriptive statistics (mean, standard deviation and percentages). For hypothesis testing, the independent sample and paired sample t-test were used. All statistical analysis were performed using the SPSS (version 11.0), and for all the analysis, a probability level of .05 was chosen to indicate statistical significance.

\section{RESULTS}

The result of study is presented in two parts. The first part consist of descriptive analysis while the second part comprises results of the hypothesis testing.

Research Question 1: What is the achievement scores of pupils taught using concept mapping strategy and those taught using the lecture method in social studies.

The result in Table 1 showed that the post-test mean achievement scores of pupils in the experimental group (those taught using the concept mapping strategy) was $63.0 \%$, with a standard deviation of 9.0, while that of pupils in the control group (those taught using the lecture method) was $49.9 \%$, with a standard deviation of 11.0 . This gives a difference of 13.1 in favour of the pupils taught using the concept mapping strategy (experimental group). This implied that pupils taught using concept mapping strategy achieved considerably higher scores than those in the control group taught using the lecture method.

Table 1. Mean achievement and standard deviation per group for pre and post-test $(n=244)$

\begin{tabular}{|c|c|c|c|c|c|}
\hline Group & Test & Mean & $\begin{array}{l}\text { Standard } \\
\text { deviation }\end{array}$ & $\mathbf{N}$ & $\%$ \\
\hline $\begin{array}{l}\text { Experimental } \\
\text { (Concept mapping) }\end{array}$ & $\begin{array}{l}\text { Pre } \\
\text { Post }\end{array}$ & $\begin{array}{l}45.0 \\
63.0\end{array}$ & $\begin{array}{l}0.45 \\
9.0\end{array}$ & 123 & 40.0 \\
\hline $\begin{array}{l}\text { Control } \\
\text { (Lecture method) }\end{array}$ & $\begin{array}{l}\text { Pre } \\
\text { Post }\end{array}$ & $\begin{array}{l}43.8 \\
49.9\end{array}$ & $\begin{array}{l}2.72 \\
11.0\end{array}$ & 121 & 13.9 \\
\hline
\end{tabular}

Research Question 2: What is the mean retention scores of pupils taught using the concept mapping strategy and those taught using lecture method in social studies.

Results in Table 2 showed that the mean retention scores of the experimental group (those taught using the concept mapping strategy) was $52.2 \%$, while that of the control group (those taught using the lecture method) was $51.3 \%$, thus the retention scores of the experimental group was higher than that of the control group. The difference was 0.9 in favour of the experimental group. 
Table 2. Mean retention scores of participants $(n=244)$

\begin{tabular}{|llllll|}
\hline Group & N & Mean & $\begin{array}{l}\text { Standard } \\
\text { deviation }\end{array}$ & t value & Sig. \\
\hline $\begin{array}{l}\text { Experimental } \\
\text { (Concept mapping) }\end{array}$ & 123 & 52.2 & 21.8 & 0.381 & 0.703 \\
& 121 & 51.3 & 14.0 & \\
$\begin{array}{l}\text { Control } \\
\text { (Lecture method) }\end{array}$ & & & & \\
& & & & \\
\hline
\end{tabular}

Hypothesis 1: There is no significant difference in the mean achievement scores between pupils taught using the concept mapping strategy and those taught using the lecture method.

The results in Table 3 revealed that greater percentage of pupils recorded a higher achievement score when concept mapping technique was used for learning. There was significant difference in the mean achievement scores between pupils taught using concept mapping (experimental group) and those taught using the lecture method (control group). The t-calculated value of 3.66 was higher than the t-critical value of 1.96 , thus the hypothesis was rejected.

Table 3. t-test comparison on mean achievement scores of pupils taught using concept mapping and lecture method.

\begin{tabular}{|lccccccc|}
\hline Group & $\mathbf{N}$ & $\%$ & Mean & $\begin{array}{l}\text { Mean } \\
\text { difference }\end{array}$ & Df & t-cal. & t-crit. \\
\hline $\begin{array}{l}\text { Experimental } \\
\text { (Concept mapping) }\end{array}$ & 123 & 50.4 & 63.0 & 18.0 & 120 & 3.66 & 1.96 \\
$\begin{array}{l}\text { Control } \\
\text { (Lecture method) }\end{array}$ & 121 & 49.6 & 45.0 & & & & \\
$*$ \\
$P<0.05$
\end{tabular}

Hypothesis 2: There is no significant difference between the mean retention scores of pupils taught using concept mapping and those taught using the lecture method.

Results in Table 4 showed that there was no significant difference in the mean retention scores of pupils taught using the concept mapping strategy (experimental group) and those taught using the lecture method (control group). The obtained t-calculated value of 0.381 was less than the t-critical value of 1.96, thus the hypothesis was not rejected. 
Table 4. t-test comparison on mean retention scores of pupils taught using concept mapping and lecture method.

\begin{tabular}{|c|c|c|c|c|c|c|c|c|}
\hline Group & $\mathbf{N}$ & $\%$ & Mean & $\begin{array}{l}\text { Mean } \\
\text { difference }\end{array}$ & Df & t-cal. & t-crit. & $\mathbf{P}$ \\
\hline $\begin{array}{l}\text { Experimental } \\
\text { (Concept mapping) }\end{array}$ & 123 & 50.4 & 52.2 & 0.90 & 120 & 0.381 & 1.96 & $<0.05$ \\
\hline $\begin{array}{l}\text { Control } \\
\text { (Lecture method) }\end{array}$ & 121 & 49.6 & 51.3 & & & & & \\
\hline
\end{tabular}

\section{DISCUSSION}

\subsection{Achievement score and significance}

The higher scores achieved by pupils in the experimental group (those taught using the concept mapping strategy) agreed with the finding of Ezeudu (1995) who reported that concept mapping strategy enhances pupils performance in basic studies. He also revealed that those taught using the concept mapping strategy at the primary school level, at Nsukka, Nigeria, obtained a higher mean achievement score of 51.2, while those taught using the conventional method obtained a lower mean achievement score of 44.3. This view also supports Nekang (2004) who reported that students taught Elementary probability with the use of concept mapping technique performed better than the students taught with the traditional lecture method.

The significant difference in mean achievement score recorded in favour of pupils taught using concept mapping strategy in social studies agreed with the result of Nworgu (2003), who reported significant difference in mean achievement score recorded in favour of senior secondary school students taught using concept mapping strategy in the teaching of algebra.

\subsection{Retention score and significance}

Investigation on the effects of concept mapping on student's retention in selected units of organic chemistry was conducted by Ezeudu (1995). She reported that secondary school students taught using the concept mapping strategy showed a better retention ability as compared to those taught using the lecture method. She concluded that concept mapping helps students retain more concepts and should be taken seriously by educators and teachers. Similar results were reported by Nekang (2004) for primary school pupils in north-west province of Cameroon and Havva and Cemal (2008) for lower secondary school students in Istanbul province of Turkey.

The no significant difference obtained in the mean retention score of pupils taught using concept mapping strategy and those taught using the lecture method is in line with that of Kinchin (2000) who reported that the instructional methods used (concept mapping strategy and lecture method) had no significant effect on pupils retention in integrated science at the primary school stage, but contradict the result of Nekang (2004) who reported that students taught with concept mapping strategy significantly retained concepts better than their counterparts in the control group in Elementary probability. The reason for the contradiction in results could be due to the method of approach in topic presentation, irrespective of the teaching strategy used. The method of approach is very vital in any teaching-learning situation. The way the content of a subject matter is presented to the learner may make the learner like or dislike the subject matter or the teacher. 


\section{CONCLUSION}

It can be concluded that the achievement and retention scores of primary school (six) pupils in social studies was higher using the concept mapping strategy compared to lecture method. On hypothesis testing, though there was significant difference in mean achievement scores of the pupils taught using concept mapping over those taught using the lecture method, however, the retention score of pupils taught using both teaching strategies was not significantly different.

\section{RECOMMENDATION}

Though, the use of concept mapping is recommended as an effective teaching strategy in improving academic performance in social studies at the public primary schools in Makurdi, Nigeria, however, future study could focus on the effects of such teaching strategies on other school types, such as private and missionary schools.

\section{References}

[1] Ali, A. (1996). Fundamental of research in education. Meks Publishers, Awka, Nigeria, p. 31.

[2] Ezeudu, F.O. (1995). The effect of concept mapping on students achievement, interest and retention in basic studies. Unpublished Ph.D Thesis, Faculty of Education, University of Nigeria, Nsukka.

[3] FRN, (2004). National policy on education. $4^{\text {th }}$ edition, Pelcam Press, Abuja, Nigeria, p. 22.

[4] Havva, V. and Cemal, V. (2008). "Concept mapping in Turkish grammar instruction: A quantitative and qualitative research study”, World Applied Science Journal, 5(3), 367-377.

[5] Ijoh, G.O., Famiwole, R. and Denco, E. (1996). Principles and methods of teaching. Restoration Publishers, Nsukka, Nigeria, p. 52.

[6] Imoko, B.I. and Agwagah, U.N.U. (2006). "Improving students interest in Mathematics through the concept mapping technique: A focus on gender", Journal of Research in Curriculum and Teaching, 1(1), 30-38.

[7] Kinchin, I.M. (2000). "Using concept maps to reveal understanding: A two-tier analysis". School Science Review, 81, 41-46.

[8] Nekang, F.N. (2004). Effect of concept mapping on students achievement and interest in elementary probability in Biu division of Cameroon. Unpublished M.Ed Thesis, University of Nigeria, Nsukka.

[9] Nworgu, B.G. (2003). Educational measurement and evaluation. Theory and Practice. University Trust Publishers, Nsukka, Nigeria, pp. 15-17.

[10] Okam, C.C. (2000). Approaches in the teaching of social studies. Outrite Publishers, Onitsha, Nigeria, p. 40.

[11] Ozden, M. and Gultekin, M. (2008). "The effect of brain-based learning on academic achievement and retention of knowledge in science course", Electronic Journal of Science Education, 2(1), 20-25.

[12] Shamija, T.A. (2008). Social studies education. An introductory text. Academic Press Ltd., Makurdi, Nigeria, pp. 20-25.

[13] Utulu, R.E. (2007). "Using concept mapping for effective teaching in nursery/primary and secondary schools", Benue State University Journal of Education, 8(1), 207-219. 